\title{
The Application of Quranic Interpretation, The Sunna and Ijtihad as The Source of Islamic Law
}

\author{
Prawitra Thalib, Faizal Kurniawan, Mohamad Nur Kholiq \\ Faculty of Law, Airlangga University \\ prawitra@fh.unair.ac.id
}

Submit: 14-05-2020; Review: 17-11-2020; Terbit: 04-12-2020

\begin{abstract}
The understanding of Islamic law can not be separated from the interpretation sourced from the Quran, Sunnah and Ijtihad, which later evolved into a flexible and dynamic source of Islamic law following the demands of the times. Although it has flexible and dynamic properties but the interpretation must still maintain the basic principles that remain will never change. This is very important because misunderstand the intent expressed in the Quran and Sunnah will affect the error of understanding the Islamic law itself, therefore it is important to realize that the effort of understanding is not separated from The true interpretation of the will of Allah and the Prophet Muhammad that is contained in the Quran and Sunnah. This paper seeks to introduce the foundation of the pursuits that come from the Quran, Sunnah and Ijtihad, which is done using the method of normative assessment of various references discussing the source of Islamic law. Therefore, it is expected to find the meeting point between the understanding of the Qur'an, Sunnah and Ijtihad with the effort to interpret the source of Islamic law aimed at realizing the benefit of the people.
\end{abstract}

\section{Keywords: Islamic Law, Maslahah, Source of Law.}

\begin{abstract}
Abstrak
Pemahaman hukum Islam pada hakikatnya tidak terlepas dari interpretasi yang bersumber dari Quran, Sunnah dan Ijtihad, yang kemudian berkembang menjadi sumber hukum Islam yang fleksibel dan dinamis mengikuti tuntutan zaman. sekalipun mempunyai sifat fleksibel dan dinamis namun interpretasi tersebut harus tetap mempertahankan prinsip-prinsip dasar yang tetap tidak akan pernah berubah. Hal ini amatlah penting karena salah memahami maksud yang tersurat dalam Quran dan Sunnah tersebut akan berdampak pada kesalahan pemahaman terhadap hukum Islam itu sendiri, oleh sebab itu penting untuk disadari bahwa upaya pemahaman tersebut tidak terlepas dari upaya interpretasi makna yang sesungguhnya dari kehendak Allah dan Nabi Muhammad yang tertuang di dalam Quran dan Sunnah. Tulisan ini berusaha mengenalkan fondasi pemaknaan yang berasal dari Quran, Sunnah dan Ijtihad, yang mana hal ini dilakukan menggunakan metode pengkajian normatif terhadap berbagai referensi yang membahas tentang sumber hukum Islam. Sehingga diharapkan dapat menemukan titik temu antara upaya pemahaman Al Quran, Sunnah dan Ijtihad dengan upaya interpretasi terhadap sumber hukum Islam yang bertujuan mewujudkan kemaslahatan umat.
\end{abstract}


Kata kunci: Hukum Islam, Maslahah, Sumber Hukum.

\section{Introduction}

The Quran is the undeniable main source of law for the Muslims (Abdullah Ahmed An Naim, 2004: 33-34), but sometimes the zannian (the nature of being observable), the interpretation of the zanni nature that brings the opportunity of Quranic interpretation when solving a problem that arises in the community, besides the existence of Sunna and Ijtihad that support the implementation of the Quran interpretation (Prawitra Thalib, 2016: 111). For Muslims, it is clear that the belief, devotion, and love to Prophet Muhammad Peace be upon him are ones of the factors that can unify the moslems in the bond of ukhuwah Islamiyah, but it does not apply to the non-moslems (Prawitra Thalib, 2013: 44). The explication and development or regulation of the verses of the Quran then generated the second source of Islamic law, that is Sunna. In the end of Rashidun Caliphate's reign until the reign of Umayyad dynasty, Sunnah became the most popular subject of study by the fiqh experts. This reached its peak when Caliph Umar ibn Abdul Aziz ruled. He ordered the attempt of collecting and codifying Sunna. This was intended that the presence of the codified Sunna in a systematic arrangement would facilitate to be the reference for the judges and administrators of their territories to perform their duty (Wael B. Hallq, 1997: 14). Moslems in general acknowledge that the Islamic law or Sharia derives from the Quran and Sunna which was extracted through a specific methodology (usul al-fiqh) developed by Islamic scholars in the eighth and ninth centuries (Peri Bearman, 2008: 323-324).

In its development, Sharia as a coherent system was started at the beginning of Abbasid Caliphate (750 $\mathrm{CE}$ ). This was indicated by the emergence of law schools, the collection of Prophet Muhammad Peace be upon him Sunna systematically as the second source of Sharia, and the establishment of law methodology which then known as the knowledge of foundation or 
principles understood by the mankind as the source derived from God Almighty (usul al figh) (Akbar Ahmed, 2001: 48). The previous explanation emphasizes that the law theory started from the assumption that the Quran is the holiest source of law and Muhammad Peace be upon him as Rasulullah or God's Messenger is the man who understands God's pretention the most compared to other human beings and acts in accordance with His pretention and volition in his everyday life. Muhammad Peace be upon him habits in his daily life are regarded as Sunnah and every utterance, direction, or narration he spoke is called as Hadith. The Islamic law in general recognizes two main sources of law, that is the naqli (source is the source of law that the formation does not require mujtahid's role ) and aqli (The aqli source is the source of law that the formation requires the role of mujtahid and his mind) sources of law (Sami Zubaida, 2005: 12).

From the explication above, it can be comprehended that the first source of law which is naqli is the source of law that is everlasting, permanent, definite, yet the meaning content can be analyzed deeper (interpretable). This happens so that the genuineness identity of Islam can be assured all the time. Meanwhile, the aqli source of law is the manifestation of Islamic law dynamism in answering the new emerging issue. Thus, by relying on human's mind, the Islamic law will always be up-to-date in all aspects of human's life. Herein lies the relevance that Sharia will remain appropriate in every time and place (Prawitra Thalib, 2013: 49). It is also important to remember that the source of law is not the epistemology of ushul al-fiqh since ushul al-figh is larger than the source of law and the source of law is included into the parts of ushul al-fiqh (Prawitra Thalib, 2018: 443). Therefore it is necessary to describe how to use the Quranic interpretation, The Sunna and Ijtihad as a source of Islamic law.

\section{Research Methods}

Based on Peter Mahmud Marzuki's (Peter Mahmud, 2017: 60) 
book legal research are used to solve existing legal problems. From that, this research used the type of normative legal research.

Normative legal research used prescriptive where the object of legal science is coherence between legal norms and legal principles, between legal rules and legal norms, and between individual behavior and legal norms. From the type of this research that used normative legal research it also related to doctrinal research and historical research.

Doctrinal research is a research that produces a systematic explanation of legal norms that arrange a particular legal category, analyzes the relationship between legal norms, explains difficult areas, and is expected to also provide predictions regarding the development of legal norms in the future.

While historical research approach to legal research helps untangle legal problems rooted in the past. It often provides guideposts showing how things are done before. It also explains how the beginning of the topics from the history both in terms of the law or its existences.

\section{Results and Discussion \\ The Quran}

The Quran has the highest rank as the absolute source of law that came from Allah The Almighty, then is followed by Sunnah and ijtihad, ijma and qiyas. The instruction to obey the command of Allah The Almighty and his Messenger can be found in Q.S. An-Nisa:59 (Rahmat Taufiq Hidayat, 2000: 1). Regarding the places where the verses of the Quran were revealed, the verses can be categorized into two that is the Mecca and Medina verses. The Mecca verses are the verses revealed when Muhammad Peace be upon him was still in Mecca, which was approximately 13 years. Meanwhile, the Medina verses are the verses revealed when Muhammad Peace be upon him already migrated to Medina (Juan El Campo, 2009: 571).

Regarding the chapter categorizations, The Quran is divided into 114 chapters or surah which actually means noble, high degree, or levels on a building. Every surah has 
different length. The longest surah is Al-Baqarah which consists of 286 verses and the shortest surah is AlKawthar which consists of three verses (Rahmat Taufik Hidayat, 2000: 8-9). The idea of the Quran codification into a whole manuscript (mushaf) was initially proposed by Umar ibn Khattab. This occurred because, after the battle of Yamama, about 70 qurro (the experts of reading the Quran) and huffaz (the Quran memorizers) were Shaheed, thus this raised Umar ibn Khattab's concern of the Quran's purity loss. This caused him to urge Caliph Abu Bakr to compile the Quran chapters into a standard manuscript or mushaf. Thus, there would no more fragments of the Quran that disappeared although all qurro and huffaz had deceased altogether (Juan El Campo, 2009: 572-573).

For the implementation of the codification task, Abu Bakr entrusted Zayd ibn Thabit who were assisted by Ubay ibn Ka'b, Ali ibn Abi Talib, Uthman ibn Affan, and other several qurro companions. This manuscript arrangement was based on the manuscripts written at the direction of Prophet Muhammad Peace be upon him himself. After the manuscript arrangement had completed into a mushaf, Zayd submitted it to Caliph Abu Bakr to be preserved and maintained. Then, after the decease of Abu Bakr, the preservation and maintenance of the Quran's mushaf was continued by Caliph Umar ibn Khattab, which then after he passed away, the preservation and maintenance of the mushaf was continued by his daughter, Siti Hafsah (Rachmat Taufiq Hidayat, 2008: 8-9). But in the reign of Caliph Uthman ibn Affan, there was a new problem emerging regarding the difference of kiraah (the way of reciting the Quran), since, at that time, the distribution of the Quran highly relied on the retention of Muhammad Peace be upon him companions (Sami Zubaida, 2005: 28) The content of the Quran is sometimes still general (zanni), thus the assessment and interpretation are required in understanding the content. In practice, the process during Prophet's lifetime was conducted in the form of Sunnah he 
established and then continued by the mujtahids after he deceased in the form of Ijtihad which relies on the human's mind as the gift from Allah The Almighty.

\section{Sunna}

As the second source of Islamic law, Sunna can be defined as something that came from Muhammad Peace be upon him in the forms of qaul, fi'il, or taqrir. In the last form, Sunna is also often called as Hadith and vice versa, sometimes Hadith is also called as Sunna (Maulana Muhammad, 1997: 41). But essentially, both Hadith and Sunnah have differences. Hadith is the Prophet's speech or words as the guidance, while Sunna is the Prophet's behavior or deed as the guidance. But the mention of Sunna as Hadith is also possible since Hadith records and narrates Sunnah (Juan El Campo, 2009: 645-646).

If seen from the source, Hadith can be categorized into two, that is Hadith Nabawi and Hadith Qudsi. The collection of Hadith was initiated during Muhammad Peace be upon him era and conducted by the companions, such as Abdullah ibn Amr, Abu Musa al-Ash'ari, and Abu Hurairah. In collecting Hadiths, some of the companions and followers (tabi'in) wrote them in a document and some other relied on the power of rote and memory (Sami Zubaida, 2005: 29). Other than that, the position of Sunnah as the second source of Islamic law can be seen in Q.S. An-Nisa verse 59 and 80 also Q.S. Al Hashr:7. At the time Muhammad Peace be upon him was still alive, he prohibited his companions to record his every speech or deed except the ones that were truly the revelation of Allah The Almighty. This prohibition was intended to avoid the admixture between Allah The Almighty's revelations (which were recorded on purpose) and Prophet's speech and deed during his lifetime (Juan El Campo, 2009: 278-279).

The reason Sunna was forbidden to record at that time because the unclear matters could still be asked directly to Muhammad Peace be upon him, so the preservation of Sunna Rasul during his lifetime until the Rashidun Caliphate era relied on 
the oral and memory eloquence of the companions who were still alive (Renny Supriyatni, 2011: 42). The process of Sunnah collection and recording was made official in the reign of Caliph Umar ibn Abdul Aziz who released the instruction to tadween (to document) the existing Hadiths. It was narrated by Imam Malik that Caliph Umar ibn Abdul Aziz released the following instruction: "Look and investigate the Hadiths and Sunna of Rasulullah, then write them down because I am afraid the knowledge will disappear and vanish due to the decease of Islamic scholars (ulama)." The instruction of Caliph Umar had generated the attempt of codifying the scattered Hadiths and Sunna. The Hadith codification resulted in the major/standard Hadith books named al-Kutub as-Sittah that were recognized as the valid Hadith books by the ulamas (Rachmat Taufiq Hidayat, 2008: 28-29). The validity of a Hadith is usually assessed from the history of Hadith narration, and the sequence of Hadith narrators is called as sanad. The assessment of Hadith validity will be conducted through the investigation of the sanad by the mukharrij. In doing so, the mukharrij will classify them into four division of sanad, that is ashab or sahabah (the companions), tabi'un (the followers), atba'ut tabi'in (the successors of tabi'un), and atba'u atbait tabi'in (the successors of atba'ut tabi'in) then reaching the mukharrij of the Hadith. As with the Quran, sometimes Sunna/Hadith merely regulates the general matters that requires the further interpretation process. The Sunna functions to provide explanation, information, or details toward the matters mentioned in the Quran since the Quran generally discusses the certain matters globally (mujmal) (Zainuddin Ali, 2006: 33).

\section{Results of Ijtihad}

After the Quran and Hadith, the third source of Islamic law is ijtihad which is derived from the word jahada that means the outpouring of all abilities to obtain something from various affairs (Zainuddin Ali, 2006: 38). Thus, etymologically, based on the fiqh books, ijtihad can be defined as "the concentration of all potentials 
of a fiqh expert or a mujtahid to provide the knowledge of laws." From the definition, it can be understood that ijtihad functions to extract (istinbat) the syara' law. The legal basis for the permissibility of ijtihad can be found in Q.S. AnNisa:59 which mentions that "O you who have believed, obey Allah and obey the Messenger and those in authority among you." From the verse, ulil amri or 'those in authority' is a person, both an ulama, mujtahid, or qadi, who has the ability to do ijtihad toward an issue (Yusdani, 2000: 15). Meanwhile, the Hadith which permits ijtihad to be performed is the Hadith which narrates the conversation between Muhammad Peace be upon him with Muadh ibn Jabal when Muadh was about to be delegated as the governor in Yemen. The dialogue stated that in encountering every problem, Muadh would prioritize the Quran and Sunna, but if there was a problem that was not regulated in both sources, then Muadh would solve the problem with his thoughts (Mutadha Muthahari, 1995: 8).
Ijtihad in Islam that can be said as the further process of reasoning and interpretation of the Quran and Sunna as the main sources of law cannot be separated from the function and role of the mujtahids who indeed serve for the duty. Regarding the standard for a person to be a mujtahid, Vogel, as cited by Robert Gleave, stated that: (Peri Bearman, 2008: 235) "It is hardly surprising that all the four schools, with the exception of the Hanafi, impose as a condition to qualification as judge the capacity of ijtihad, that is to say, that the appointee must be a mujtahid." Therefore, a mujtahid is preferably (in accordance with the three madhhabs except Hanafi) a judge or qadi. The relation of a qadi who serves to issue a decision (qada) and a mujtahid who serves to issue a fatwa is indeed interrelated both in theory and positive law in Islam since sometimes the decision is made based on a fatwa (Yusdani, 2000: 61).

The need of a qadi to be a mujtahid is almost universally accepted by the Islamic classical jurists (this, according to Vogel, is 
only rejected by Hanafi madhhab). This means that a qadi as a mujtahid should not only understand the law from the source of his personal investigation (Abdel Majid Sharfi, 200: 152), but he should also practice his ijtihad capability in relation to relevant facts or cases and with his capability, he then can find a law in certain cases (Murtadha Muthahhari, 1995: 51). The previous perspective can be said that a qadi also requires to play the role of a mujtahid since, in Islam, a mufti can only provide the legal opinion. Meanwhile, a qadi is not only able to provide the legal opinion, but also to implement his opinion (futya and ilzam) in certain cases (Wahbah Az-Zuhaili, 2007: 114). The previous explication can be understood that not all qadi is entitled for the legal interpretation or fatwa issuing. Only qadi with a certain knowledge, moral excellence, and competence who can conduct those duties (ahl al-ilm wal-adāla wal-kamāl). The competence meant by Ibn Barraj is comprehending the Quran, books of Sunna, consensus of Islamic scholars, dissent (particularly the four madhhabs), and Arabic language as the lingua franca of Islam (Juan El Campo, 2009: 53).

The role of mujtahid, qadi, and mufti can be said to pass their knowledge to the society whose level of knowledge is lower than them (qadi and mufti) (Salim Bahreisj, 1987: 322). This perspective concludes that in the social structure of Islamic society, the knowledge is obtained by the qadis and muftis through education and practice. Moreover, with their own knowledge through the activities of ifta and qada, then the muftis and qadis indirectly receive the charisma and high authority in the society due to their knowledge of God's law. Regarding the position of qadi as a mujtahid, Al Sabzawari argued that if the absolute mujtahid (a mujtahid who is not a qadi but has ahl al-ilm wal-adāla wal-kamāl criteria) is really not willing in a society, then the qadi can have the role of a mujtahid.

\section{Ijtihad}

There are various methods in conducting ijtihad and one of them is ijma which has the basic meaning 'to 
gather, unify, collect, united, or pull together.' Regarding the definition of ijma as a source of Islamic law, the experts of ushul al-fiqh argue that ijma is an agreement or consensus of mujtahid Imams among Muslims in a certain era after the decease of Muhammad Peace be upon him concerning a certain issue or incident. In practice, after the decease of Muhammad Peace be upon him, the interpretation process of the Quran and Sunna is only considered valid and legitimate if it is recognized by a consensus of the ijma (Abdullahi Ahmed An Naim, 2004: 39).

Another method of ijtihad is qiyas. According to the ulamas of usul, qiyas is connecting an occurrence that has no postulate (nash) with another occurrence that has any postulate in the law that has been set by the postulate due to the similarities of both occurrences in the illat (Trisadini Prasastinah Usanti dan Prawitra Thalib, 2016: 303). In other words, qiyas provides an opportunity for the mujtahids to analogize an incident that is based on the previously occurred precedent
(Abdullahi Ahmed An Naim, 2004: 41). The interpretation by analogy through qiyas provides the most extensive explanation since the legal issue that becomes the main problem being discussed is always related to the element of analogical argument (Prawitra Thalib, 2017: 223). Hence, generally, qiyas can be executed if it meets four main elements, that is the existence of a new case (far), the existence of an original case (asl) in the main sources of law, the existence of ratio legis (illat), and the existence of legal norm attributed to the new case due to the similarities of illat. In this analogy, it is assumed that a new case is the case which is not directly mentioned in the nash, yet humans need to associate the explicit provision in the text toward the new case, which in other words, the new case or far should own the similarities with the original case or asl (Wael B. Hallaq, 2000: 123). When a fiqh expert utilizes qiyas in solving an issue, then the ratio legis plays the important role in the nash interpretation as the initial reference of asl toward far. In this case, there are several primary considerations 
that should be concerned by a fiqh expert in using ratio legis. First, a fiqh expert should determine the nature of common denominator in the original and new cases in such a way, so he should be capable to convince which law to achieve through the interpretation of a nash toward the case that has no clear provision in the nash. Second, every ratio legis should be based on nash. The nash where the ratio is taken should be able to be extended to the new cases which has the similarities of illat and the application should not be limited at all. Third, the ratio legis should exist when the law exists. Fourth, the existence of a mismatch between the ratio and the law (naqd) can cause the ratio invalid. Fifth, the ratio may collapse if the opposing party can show that his ratio is more valid and results in the different law than the law achieved by the previous thinker (Yuselfri, 2019: 58).

The Islamic law also recognizes the additional techniques which are sometimes utilized as the additional sources of law in the Islamic law, that is istihsan, mashlahah mursalah, and urf. Istihsan is a favorable construction since this concept is used to avoid the utilization of the rigid qiyas. Shafi'i madhhab refuses the existence of istihsan since it tends to lead to the arbitrary decision (Abdullahi Ahme An Naim, 2004: 42). Then, maslahah mursalah is the method that has the similarity with the utility principle proposed by Jeremy Bentham. According to Bentam, the law should provide as much happiness as possible to most people, or "the greatest happiness is a greatest number." The standard used in mashlahah mursalah is the benefit to all mankind (Zainuddin Ali, 2006: 41). It is called as maslahah or maslaha (Kurniawan Edi, 2018: 176) since behind the lawmaking (tasyri'), there is an avail to provide benefits and it denies the hazard for the public interest (Abd. Shomad, $2018: 56)$. It is also called as mursalah due to the assumption which rejects or justify that. In other words, there is no reason that justifies or denies that since everything is done for the good of all moslems (Nurhadi and Muzakir, 2018: 154). Another additional source of Islamic law which is also 
often discussed is $u r f$ which is often defined as al-adah or the hereditary habits in a society Prawitra Thalib and Bagus Oktafian Abrianto, 2019: 217). According to Abdul Wahhab Khallaf, urf and al-adah are the synonyms that have similar definition, but some argued that aladah is more general and urf is a part of al-adah. Thus, the habits done repeatedly by a person is called as adat fardiyah and the habits done repeatedly by a society is called as adat jama'iyah, and the term urf is only appropriate with the second term, that is adat jama'iyah (Abd. Wahab Khallaf, 1980: 124-125).

\section{Conclusion}

Essentially, Some of the verses in the Quran are zanni or observable, this is because the Quran only regulates principles that require interpretation of the true meaning of these provisions in solving all problems faced by humans. When the Prophet Muhammad Peace be upun him was still alive the interpretation of the Quran was manifested in the form of the Sunna, which was used as a guide for
Moslems when solving a problem. However, when the Prophet Muhammad Peace be upon him passed away, efforts to interpret the Qur'an and Sunnah were continued by Islamic Legal Scholar (fuqoha) using the methods of ijtihad. Through the method of ijtihad later the results of these interpretations will certainly not conflict with the Quran and Sunnah. Which results from the interpretation of the Quran and Sunnah will later become the source of Islamic law, which will give solution to the certain legal issues that rise in society.

\section{Bibliography}

Books

Ahmed, Akbar, 2001, Discovering Islam Making Sense of Muslim History and Society, Routledge Great Britain : Revised Edition.

Ali, Maulana Muhammad, 1977, Islamologi (Dinul Islam), Jakarta: PT. Ichtiar Baru Van Hoeve.

Ali, Zainuddin, 2006, Filsafat Hukum, $1^{\text {st }}$ Edition, Jakarta: Sinar Grafika.

An Naim, Abdullah Ahmed, 2004, Dekonstruksi Syariah Wacana Kebebasan Sipil, Hak Asasi Manusia dan 
Hubungan Internasional Dalam Islam, $4^{\text {th }}$ Edition, Yogyakarta: Institute for Islamic and Social Studies.

Az-Zuhaili, Wahbah, 2007, Fiqh Islam Wa Adilla Tuhu. Jilid 8. Jihad, Pengadilan dan Mekanisme Mengambil Keputusan, Pemerintahan Dalam Islam, 10 ${ }^{\text {th }}$ Edition, Gema Insani.

Bahreisj, Salim, 1987, Tarjamah Riadhus Shalihin II, $10^{\text {th }}$ Edition, Bandung: PT Al Ma'arif, Bandung.

Bearman, Peri, et al., 2008, The Law Applied Contextualizing The Islamic Shari'a, London: I.B. Tauris \& Co Ltd

El Campo, Juan, 2009, Encyclopedia of Islam, An Imprint of Infobase Publishing, United States of America.

Hallaq, Wael B., 1997, A History of Islamic Legal Theories, an Introduction to Sunni usul al- fiqh, $1^{\text {st }}$ Edition, Cambridge: University Press. ,2000, Sejarah Teori Hukum Islam, Pengantar Untuk Ushul Fiqh Mazhab Sunni, $1^{\text {st }}$ Edition, Jakarta: RajaGrafindo Persada.

Hidayat, Rahmat Taufiq, et al., 2000, Almanak Alam Islami. $1^{\text {st }}$ Edition, Jakarta : PT Dunia Pustaka Jaya.
Murtadha Muthahhari, 1995, PrinsipPrinsip Ijtihad Antara Sunnah dan Syiah, $2^{\text {nd }}$ Edition, Bandung: Pustaka Hidayah, Bandung.

Khallaf, Abd. Wahab, 1980, KaidahKaidah Hukum Islam (Usul Fiqh), Yogyakarta: Penerbit Nur Cahaya.

Sharfi, Abdel Majid, 2005,Islam Between Divine Message and History, First Published, Hungary: Central European University Press.

Supriyatni, Renny, 2011, Pengantar Hukum Islam Dasar-Dasar Dan Aktualisasinya Dalam Hukum Positif, Bandung: Widya Padjadjaran.

Mahmud Marzuki, Peter, 2019, Penelitian Hukum Edisi Revisi, Jakarta: Kencana Prenada Media Group.

Prawitra Thalib, 2013, Syariah: Konsep dan Hermemeutika, $1^{\text {st }}$ Edition, Surabaya: Lutfansyah Mediatama, Surabaya.

Yusdani, 2000, Peranan Kepentingan Umum Dalam Reaktualisasi Hukum: Kajian Konsep Hukum Islam Najamuddin At-Tufi, Cetakan Pertama, Yogyakarta: UII Press.

Zubaida, Sami, 2005, Law And Power In The Islamic World, London: I.B. Tauris \& Co Ltd. 


\section{Journals}

Kurniawan, Edi, 2018, "Distorsi Terhadap Maqasid AlSyari'ah Al-Syatibi di Indonesia", Jurnal AlRisalah, Vol. 18, No. 2.

Nurhadi and Muzakir, 2018, "The Wisdom of Syari'ah alahwal al-sakhsiyyah According To Ali Ahmad Al-Jurjawi", Jurnal AlRisalah, Vol. 18, No. 2.

Shomad, Abd, 2017, "Financing Risks of Micro, Small and Medium Enterprises (UMKM) With Cooperation Patterns Between Islamic Bank and Baitul Maal Wa Tamwil (BMT)", Jurnal Dinamika Hukum, Vol.17, No. 1.

Thalib, Prawitra, 2016, “Application of Qowaid Fiqhiyyah in Contemporary Islamic Law", Yuridika, Vol. 31, No. 1.

Thalib, Prawitra, 2018, "Distinction of Characteristics Sharia and Fiqh on Islamic law", Yuridika Vol. 33, No. 3.

Thalib, Prawitra and Bagus Oktafian Abrianto, 2019, "The Comparative Study of Fiqh Siyasah With The General Principles of Good Government in Indonesia", Arena Hukum, Vol. 12, No. 2.

Usanti, Trisadini Prasastinah dan Prawitra Thalib, 2016,
“Asas Ikhtiyati Pada Akad Pembiayaan Mudharabah Di Lingkungan Perbankan Syariah", Yuridika Vol. 31, No. 2.

Yuselfri, 2019, "Penggunaan Qiyâs Dalam Fatwa-Fatwa Dewan Syariah Partai Keadilan Sejahtera", Jurnal AlRisalah, Vol. 19, No. 1.

\section{Proceedings}

Thalib, Prawitra, et.al., 2017, "Hisbah (Supervision) Application in Determining of Standarize Standard Akad Modes on Islamic Finanacial Institution in Indonesia" (paper presented at the International Conference on Law, Governance and Globalization 2017 ICLGG 2017, Surabaya, East Java, November 15-16). 